\title{
Zinc Finger Protein ZIC 4
}

National Cancer Institute

\section{Source}

National Cancer Institute. Zinc Finger Protein ZIC 4. NCI Thesaurus. Code C75549.

Zinc finger protein ZIC 4 (334 aa, $37 \mathrm{kDa}$ ) is encoded by the human ZIC4 gene. This protein may play a role in transcriptional regulation and DNA binding. 